\title{
Prevalence of Virulence Genes Associated with Diarrheagenic Pathotypes of Escherichia coli Isolates from Water, Sediment, Fish, and Crab in Aby Lagoon, Côte d'Ivoire
}

\author{
Ollo Kambire, ${ }^{1}$ Ama Antoinette Adingra, ${ }^{2}$ Konan Mathurin Yao, ${ }^{1}$ and Rose Koffi-Nevry ${ }^{3}$ \\ ${ }^{1}$ Department of Biochemistry and Food Sciences, University of Peleforo Gon Coulibaly, BP 1328, Korhogo, Côte d'Ivoire \\ ${ }^{2}$ Laboratory of Microbiology, Oceanographic Research Center, BP V 18, Abidjan, Côte d'Ivoire \\ ${ }^{3}$ Laboratory of Biotechnology and Food Microbiology (UFR/STA), University of Nangui Abrogoua, 02 BP 801 Abidjan, Côte d'Ivoire \\ Correspondence should be addressed to Ollo Kambire; kam_ollo@yahoo.fr
}

Received 17 January 2017; Accepted 27 April 2017; Published 6 June 2017

Academic Editor: Marcel H. Zwietering

Copyright ( 2017 Ollo Kambire et al. This is an open access article distributed under the Creative Commons Attribution License, which permits unrestricted use, distribution, and reproduction in any medium, provided the original work is properly cited.

\begin{abstract}
This study was conducted to characterize virulence genes of Escherichia coli isolates from water, sediment, fish, and crab in Aby Lagoon. Serogrouping was performed by EPEC antisera in $113 \mathrm{E}$. coli strains. The presence of diarrhea-associated genes (eae, stx, AggR, elt, and est) was assessed by multiplex PCR using specific primers. Based on the multiplex PCR, sixty-two isolates (42 from water, 19 from sediment, and 1 from crab) were positive for virulence genes, including 34 positive for elt (ETEC), 46 positive for est (ETEC), 24 positive for both elt and est, 6 positive for $s t x$ (EHEC), 1 positive for both $s t x+$ est, and 1 positive for both stx + elt. Genes eae (EPEC) and AggR (EAEC) were not detected. Nine serogroups (O114, O127, O55, O111, O86, O119, O126, O128, and O142) were identified. This study revealed the presence of diarrheagenic and nondiarrheagenic E. coli and potential public health risks if fishery products are not appropriately cooked.
\end{abstract}

\section{Introduction}

Most Escherichia coli strains are a normal inhabitant of the intestinal tract of humans and warm-blooded animals. Despite being usually harmless, various E. coli strains have acquired genetic determinants (virulence genes) giving them the capacity to cause illness for both humans and animals. Some strains of $E$. coli are now seen as pathogenic species with remarkable versatility in their ability to cause disease in humans and animals [1]. E. coli is one of the most frequent causes of diarrhea in children in developing countries [2]. According to Grasso et al. [3] and Tumwine et al. [4], infectious pathotypes of $E$. coli are related to the lack of sanitation and personal hygiene but also the consumption of well water, river water, and other contaminated surface waters.

Diarrheagenic E. coli (DEC) is classified on the basis of its epidemiological, clinical, and pathogenic characteristics into the following six different pathotypes: enteropathogenic E. coli (EPEC), shiga-toxin producing E. coli (STEC) or enterohemorrhagic E. coli (EHEC), enterotoxigenic E. coli (ETEC), enteroinvasive E. coli (EIEC), enteroaggregative $E$. coli (EAEC), and diffuse adherent E. coli (DAEC) [1]. Each pathotype expresses a unique set of virulence and colonization factors encoded in the chromosome or in episomal structures [5]. The genes encoding these virulence factors are conserved among strains isolated from different continents [6-9].

Among the E. coli pathogenic strains, in most developing countries, EPEC, ETEC, and EAEC are the most common cause of infectious diarrhea in young children [10, 11]. Research into EPEC is intense and provides a good virulence model of other E. coli infections as well as other pathogenic bacteria [12]. According to the World Health Organization (WHO) in 1987, most EPEC strains belonged to a series of $\mathrm{O}$ antigenic groups known as EPEC serogroups which included O26, O55, O86, O111, O114, O119, O125, O126, O127, O128, O142, and O158 [13]. Serogrouping of E. coli based on somatic $\mathrm{O}$ antigen used for differentiating diarrheagenic E. coli is costly and time-consuming and poorly correlates 


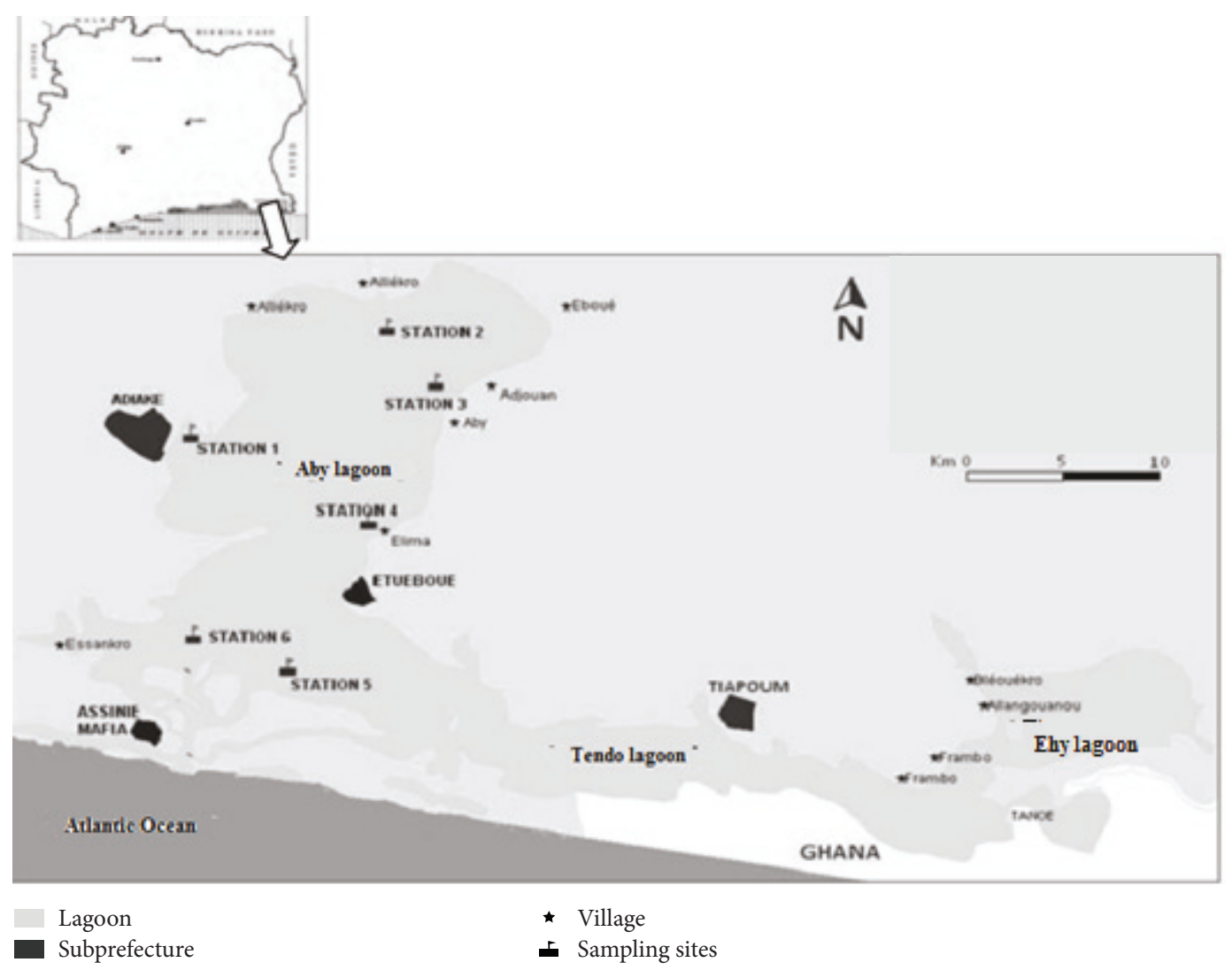

FIGURE 1: Study area and sampling stations [21].

with the presence of virulence factors. So, in the last decade, modern molecular detection methods were reported in the literature for rapid identification of $E$. coli pathotypes including PCR and multiplex PCR.

In spite of increasing evidence that E. coli strains originating from human and animal feces contain several virulence genes, only a few studies have investigated the presence of $E$. coli pathotype in environmental waters [14-18]. The presence of $E$. coli strains with virulence genes profiles similar to EHEC, EPEC, and ETEC in environmental waters has already been reported. To the best of our knowledge, no investigation on $E$. coli pathotypes distribution has been carried out on the estuarine water environments of Côte d'Ivoire. Yet, these environments that receive frequently domestic wastewater and mammalian feces provide important fishery resources. The production of fish and shellfish is estimated, respectively, to be 6.000 and 7.000 tons per year in the Aby Lagoon [19]. Contamination of lagoon waters by $E$. coli pathotypes could have a negative impact on fish, crabs, and other animals in this environment. Thus, a potential public health risk exists if these fishery products were contaminated by these pathotypes on the one hand and on the other hand if the hygiene measures are faulty during cooking. According to Rangel et al. [20], exposure to recreational waters has been linked to high numbers (21 out of 31 ) of reported E. coli O157:H7 disease outbreaks in the United States from 1982 to 2002. In addition, direct ingestion or aerosols of contaminated water during spray irrigation and contaminated vegetable could cause infection.

The aim of this study was to use PCR method to detect four pathotypes of E. coli (ETEC, EPEC, EAEC, and EHEC) from water, sediment, fish, and crab samples. During the study, both PCR and culture-based methods were used.

\section{Materials and Methods}

2.1. Sampling Sites. The Aby Lagoon is located between $2^{\circ} 51$ and $3^{\circ} 21$ eastern longitude and $5^{\circ} 05$ and $5^{\circ} 22$ northern latitude southeast. The two main tributaries (Bia and Tanoe) are escape routes from anthropogenic and mining operations within Aby Lagoon's watershed in Côte d'Ivoire and Ghana (Figure 1). Six sampling stations spread throughout the Aby Lagoon were selected in view of the fact that these stations were subject to various discharges (wastewater, excreta). Station 1 is located near an urban area. Swimming and fishing are practiced here. Station 2 located at the mouth of the river Bia is a fishing zone. Stations 3 and 6, located, respectively, near the latrine on the pile of the Aby and Assomlan villages, are sites where recreational activities are constantly practiced. Stations 4 and 5 are fishing zones.

2.2. Sampling. Six campaigns were carried out from June 2010 to March 2011 for the collection of water, sediment, fish, and 
TABLE 1: Primers used for PCR in this study [23].

\begin{tabular}{|c|c|c|c|}
\hline Genes & Sequence $\left(5^{\prime}\right.$ to $\left.3^{\prime}\right)$ & Size (bp) & References \\
\hline Eae & $\begin{array}{l}\text { F CCC GAA TTC GGC ACA AGC ATA AGC } \\
\text { R CCC GGA TCC GTC TCG CCA GTA TTC G }\end{array}$ & 881 & {$[24]$} \\
\hline Stx & $\begin{array}{l}\text { F GAG CGA AAT AAT TTATAT GTG } \\
\text { R TGA TGA TGG CAA TTC AGT AT }\end{array}$ & 518 & {$[25]$} \\
\hline $\operatorname{Agg} R$ & $\begin{array}{l}\text { F GTA TAC ACA AAA GAA GGA AGC } \\
\text { R ACA GAA TCG TCA GCA TCA GC }\end{array}$ & 254 & [26] \\
\hline Elt & $\begin{array}{c}\text { F TCTCTATGTGCATACGGAGC } \\
\text { R CCATACTGATTGCCGCAAT }\end{array}$ & 322 & [27] \\
\hline Est & $\begin{array}{l}\text { F TTAATAGCACCCGGTACAAGCAGG } \\
\text { R CCTGACTCTTCAAAAGAGAAAATTAC }\end{array}$ & 147 & {$[28]$} \\
\hline
\end{tabular}

crab samples. These six campaigns are distributed as follows: two campaigns for the rainy season (June-July), two for the flood season (September-October), and two for the dry season (February-March). At each sampling point, samples of water were collected in sterile glass bottles and those of sediments in stomacher bags. Samples of fish and crabs obtained from fishermen in Aby Lagoon were collected in stomacher bags. A total of 72 water samples and 36 sediment samples were analyzed, consisting of 12 water samples and six sediment samples collected per campaign. Thirty-six fish samples and 36 crab samples were analyzed, with six samples collected per campaign for each. A total of 180 lagoon samples were collected. Collected samples were transported to the laboratory in a cooler containing ice.

2.3. Isolation of Escherichia coli Strains. A total of 113 strains of $E$. coli were isolated from 72 samples of water, 36 samples of sediment, 36 samples of fish, and 36 samples of crab. $E$. coli isolates from water and sediment were obtained on Eosin Methyl Blue agar (EMB, BIOKAR) through the membrane filtration method. Briefly, $5 \mathrm{~mL}$ and $10 \mathrm{~mL}$ of water samples were filtered through $0.45 \mu \mathrm{m}$ cellulose membrane filters (Millipore, Sartorius Stedim Biotech, Germany) and placed on Eosin Methyl Blue agar. For sediment analysis, dilutions $\left(10^{-1}, 10^{-2}\right)$ were first performed with sterile buffer peptone water, and then volumes of $5 \mathrm{~mL}$ and $10 \mathrm{~mL}$ of each diluted sample were filtered as previously described and placed on Eosin Methyl Blue agar. For fish and crab analysis, $25 \mathrm{~g}$ of gut, flesh, and gills of fish and of gut and shell of crab from each sample was added to $225 \mathrm{~mL}$ of sterile buffer peptone water contained in a plastic stomacher bag and mixed. Decimal dilutions from this solution were then carried out in buffer peptone water. E. coli isolates from fish and crabs were obtained with desoxycholate agar (Becton Dickinson $\mathrm{GmbH}$ ). All the Petri dishes were incubated at $44.5^{\circ} \mathrm{C}$ for 24 hours. In addition, isolates were purified on EMB, a selective medium for enterobacteria, and incubated as before. Metallic sheen colonies showing a dark central spot [22] were used as presumptive E. coli. Presumptive E. coli strains with positive indol, negative citrate, and negative urea were confirmed as $E$. coli. E. coli strain of American Type Culture Collection 25922 (ATCC 25922) was used as the control.
2.4. Detection of Virulence Genes by PCR. DNA of each isolate was extracted according to the boiling method. Approximately 5 to 10 colonies of an overnight bacterial culture were taken and suspended in $100 \mu \mathrm{L}$ of distilled water. The mixture was stored at $-20^{\circ} \mathrm{C}$ for $10 \mathrm{~min}$ and then boiled at $100^{\circ} \mathrm{C}$ for $10 \mathrm{~min}$. After centrifugation in a Mikro 220R Hettich centrifuge at 14000 RPM for $10 \mathrm{~min}$, supernatants were used for PCR amplification. The amplification reactions were carried out in a reaction mixture of $25 \mu \mathrm{L}$ containing $10 \mu \mathrm{L}$ of Master Mix 1x (5PRIME Hot Master Mix 2.5x Dominique DUTSCHER) (France), $1.4 \mu \mathrm{M}$ concentration (each) of primers (Table 1), and $5 \mu \mathrm{L}$ of the DNA template. The PCR amplification was performed using a thermocycler system (Applied Biosystems, 2720 Thermal Cycler, USA). The amplification program included an initial denaturation step at $94^{\circ} \mathrm{C}$ for $2 \mathrm{~min}$, followed by 30 cycles of denaturation $\left(94^{\circ} \mathrm{C}\right.$ for $1 \mathrm{~min})$, primer annealing $\left(52^{\circ} \mathrm{C}\right.$ for $\left.1 \mathrm{~min}\right)$, and extension $\left(65^{\circ} \mathrm{C}\right.$ for $\left.1 \mathrm{~min}\right)$, with a final extension at $65^{\circ} \mathrm{C}$ for $10 \mathrm{~min}$. PCR products $(10 \mu \mathrm{L})$ were resolved by electrophoresis on a $2.5 \%$ agarose gel (Promega, USA) at $120 \mathrm{mV}$ for $80 \mathrm{~min}$. Agarose gel was then stained with ethidium bromide (SigmaAldrich, USA), and the DNA bands were visualized and photographed under UV illumination (UV UVItec, UK). The buffer in the electrophoresis chamber (PCR SCIE-PLAS, China) and in the agarose gel was $1 x$ Tris-borate-EDTA (89 mM Tris-borate, $2.5 \mathrm{mM}$ EDTA).

2.5. Serogrouping of E. coli Isolates. Detection of virulence strains among the $113 \mathrm{E}$. coli isolates was performed by $\mathrm{O}$ serogrouping with 12 antisera (Bio-Rad) by the slide agglutination method according to the manufacturer's instructions. The 12 immune sera tested in this study were O55, O26, O111, O86, O119, O127, O125, O126, O128, O114, O124, and O142.

\section{Results}

Sixty-two strains (55\%) of the 113 strains tested were positive for virulence genes. Pathogenic strains of $E$. coli were more isolated in the sediment with a frequency of $70 \%$ of the cases, followed by the strains from water $(68 \%)$. Virulence strains were least observed with the crabs (9\%). No pathogenic strain of $E$. coli was detected in fish samples (Table 2). 
TABLE 2: Distribution of E. coli strains.

\begin{tabular}{|c|c|c|c|c|c|}
\hline & & & & & Total \\
\hline & Water & Sediment & Fish & Crab & Iotal \\
\hline Number of strains & 62 & 27 & 13 & 11 & 113 \\
\hline Pathogenic strains & $42(68 \%)$ & $19(70 \%)$ & $0(0)$ & $1(9 \%)$ & $62(55 \%)$ \\
\hline Nonpathogenic strains & $20(32 \%)$ & $8(30 \%)$ & $13(100 \%)$ & $10(91 \%)$ & $51(45 \%)$ \\
\hline
\end{tabular}

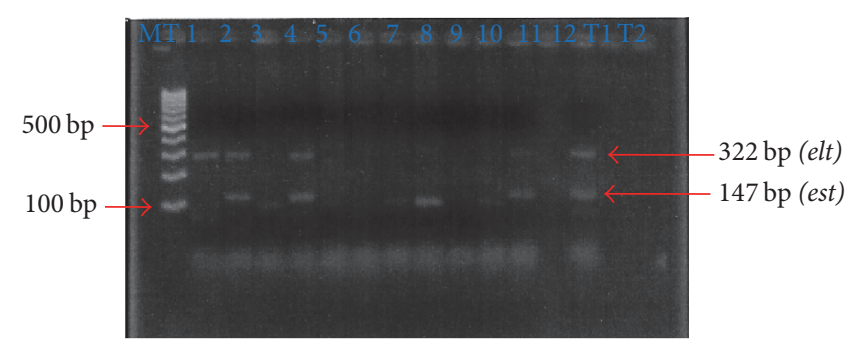

FIGURE 2: Gel electrophoresis profile of different virulence genes of the potential diarrheagenic E. coli isolates. Lane MT: molecular size marker (100 bp DNA ladder). Lane 1: elt; lanes 2 and 4: elt and est; lanes 3, 5, 6, 7, 9, 10, and 12: nonpathogenic E. coli; lanes 8 and 11: est; T1: positive control (est, elt); T2: negative control.

TABLE 3: Prevalence of E. coli pathotypes.

\begin{tabular}{lccccc}
\hline \multirow{2}{*}{ Source } & \multicolumn{5}{c}{ Frequency (\%) } \\
& Water & Sediment & Fish & Crab & Total \\
\hline Pathotype groups & & & & & \\
EPEC & 0 & 0 & 0 & 0 & 0 \\
EHEC & $5(8 \%)$ & $1(2 \%)$ & 0 & 0 & $6(10 \%)$ \\
EAEC & 0 & 0 & 0 & 0 & 0 \\
ETEC & $37(60 \%)$ & $18(29 \%)$ & 0 & $1(2 \%)$ & $56(90 \%)$ \\
Total & $42(68 \%)$ & $19(31 \%)$ & 0 & $1(2 \%)$ & $62(100 \%)$ \\
\hline
\end{tabular}

The four pathotypes of E. coli in this study according to the nature of the samples analyzed are shown in Table 3. Two $E$. coli pathotypes were identified, namely, enterotoxigenic $E$. coli (ETEC) with a percentage of $90 \%$ and enterohemorrhagic E. coli (EHEC) with a prevalence of $10 \%$. These two pathotypes were observed in the samples of water, sediments, and crab. In water samples, $8 \%$ and $60 \%$ of the pathogenic strains belonged to EHEC and ETEC, respectively. For sediment samples, $2 \%$ of the cases of the virulent strains belonged to EHEC and 29\% to ETEC. No strains of enteropathogenic E. coli (EPEC) and enteroaggregative E. coli (EAEC) were identified. The only pathogenic strain identified in the crab samples belonged to ETEC.

Table 4 shows the prevalence of virulence genes according to the nature of the samples examined. The genes belonging to ETEC were the most detected with a frequency of $74 \%$ and $55 \%$ of the cases for the genes "est" and "elt," respectively. These genes were identified in strains isolated from water, sediment, and crabs with the most important prevalence from the water samples (32\% for "elt" gene and 50\% for "est" gene). The ETEC strains harboring "est" gene were the most identified (74\%). A prevalence of $35 \%$ of these strains possessed both the heat-labile toxin gene (elt) and the heatstable toxin gene (est). About $10 \%$ of enterohemorrhagic $E$. coli (EHEC) harbored "stx" gene. The simultaneous presence of genes st $x+$ est and elt + stx was also identified in some strains with a prevalence of $2 \%$ for each combination. Figure 2 shows the PCR amplification products of the target genes studies.

The various serogroups of potential pathogenic E. coli according to the nature of samples are shown in Table 5. The results of the serogrouping by antisera showed that $37 \%$ of the 62 pathogenic E. coli isolates were typeable with the used antisera. Nine serogroups, namely, O114 (14\%), O127 (6\%), $\mathrm{O} 55$ (5\%), and 2\% for O111, O86, O119, O126, O128, and O142, were identified. The O114 serogroup was the most detected. Different serogroups identified are not specific to each group of pathotype (Table 6).

\section{Discussion}

Results of the prevalence of potential pathogenic E. coli strains found in water (68\%) and sediment (70\%) samples were similar to those reported by Obi et al. [14] from water and sediment of six rivers in South Africa. These results could be explained by the fact that this lagoon received all effluents. Indeed, several effluents are released often without any treatment in the lagoon. Kambiré et al. [29] showed that the Aby Lagoon was influenced by continental waters. In addition, these authors indicated that most of the household members (93\%) living in places without latrines defecated directly into the lagoon. The prevalence of nonpathogenic E. coli was $45 \%$. According to Bekal et al. [30], Escherichia coli is a normal inhabitant of the intestinal tract of humans and warmblooded animals. Despite being usually harmless, various 
TABLE 4: Prevalence of virulence genes.

\begin{tabular}{|c|c|c|c|c|c|c|}
\hline \multirow{3}{*}{$\begin{array}{l}\text { Pathotype groups } \\
\text { Genes }\end{array}$} & \multicolumn{6}{|c|}{ Frequency } \\
\hline & & ETEC & & EHEC & & \\
\hline & elt & est & elt + est & $s t x$ & $s t x+e s t$ & $s t x+e l t$ \\
\hline \multicolumn{7}{|l|}{ Source } \\
\hline Water & $20(32 \%)$ & $31(50 \%)$ & $12(19 \%)$ & $5(8 \%)$ & $1(2 \%)$ & $1(2 \%)$ \\
\hline Sediment & $13(21 \%)$ & $14(22 \%)$ & $9(14 \%)$ & $1(2 \%)$ & 0 & 0 \\
\hline Crab & $1(2 \%)$ & $1(2 \%)$ & $1(2 \%)$ & 0 & 0 & 0 \\
\hline Total & $34(55 \%)$ & $46(74 \%)$ & $24(35 \%)$ & $6(10 \%)$ & $1(2 \%)$ & $1(2 \%)$ \\
\hline
\end{tabular}

TABLE 5: Serogroups of potential pathogenic strains typeable.

\begin{tabular}{lcccc}
\hline Serogroups & Water & Sediment & Crabs & Total \\
\hline O55 & 2 & 1 & 0 & $3(5 \%)$ \\
O26 & 0 & 0 & 0 & 0 \\
O111 & 1 & 0 & 0 & $1(2 \%)$ \\
O86 & 1 & 0 & 0 & $1(2 \%)$ \\
O119 & 1 & 0 & 0 & $1(2 \%)$ \\
O127 & 3 & 1 & 0 & $4(6 \%)$ \\
O125 & 0 & 0 & 0 & 0 \\
O126 & 1 & 0 & 0 & $1(2 \%)$ \\
O128 & 1 & 0 & 0 & $1(2 \%)$ \\
O114 & 3 & 5 & 1 & $9(14 \%)$ \\
O124 & 0 & 0 & 0 & 0 \\
O142 & 1 & 0 & 0 & $1(2 \%)$ \\
Total N (\%) & $14(23 \%)$ & $7(12 \%)$ & $1(2 \%)$ & $22(37 \%)$ \\
\hline
\end{tabular}

E. coli strains have acquired genetic determinants (virulence genes) rendering them pathogenic for both humans and animals.

The pathogenic E. coli strains found in this study belong to two different pathotypes: ETEC and EHEC. ETEC (90\%) represents the most frequent pathotype. This result is similar to those reported by Salem et al. [6]. ETEC was identified as the common cause of infections among tourists visiting Asia, Africa, and South America and also as a common diarrheal pathogen in children in many developing countries of Asia, Africa, and South America [31, 32].

The prevalence of heat-stable toxin gene (est) of ETEC was $74 \%$ of the strains tested compared to the heat-labile toxin gene $(l t), 55 \%$. Other studies showed predominance of "est" gene [33, 34]. Several authors have also reported the simultaneous presence of the genes est and $l t$ in ETEC $[32,35,36]$ like in this study. According to Munshi et al. [37], the genes encoding LT (elt or etx) reside on plasmids that also may contain genes (est) encoding ST.

The prevalence of EHEC pathotype was $10 \%$. This frequency is lower than that obtained by Ndlovu et al. [15] which was $15 \%$ in their study on the characterization of $E$. coli isolated from surface water sources. However, frequency in this study is higher than that obtained by Obi et al. [14] which was
$2 \%$ in South African rivers. Our prevalence is approximately similar to those reported by Dadié et al. [38] in 1780 samples of food (meat and dairy products) and 1416 patients in Côte d'Ivoire. One isolate harbored the combination of stx and elt genes and another stx and est genes. An association gene was also observed by Moalic and Guennec [39] from E. coli strain causing diarrhea in pigs in France. According to Titilawo et al. [16], the lower prevalence of the EHEC pathotype compared to other pathotypes suggests that human fecal contamination is the main source of diarrheagenic E. coli pathotypes in the surface water as opposed to contamination from animals. Contrary to the studies of Sidhu et al. [40] and Titilawo et al. [16] in the characterization of E. coli from surface water and rivers in Southwestern Nigeria, respectively, genes for EPEC (eae) and EAEC (AggR) were not detected in this study.

Phenotype assays such as serogrouping with traditional antisera are the routine methods that have been widely used in clinical laboratories [41]. Serogrouping has been shown to be insufficient for the identification of a particular pathotype group. The 12 antisera specific for EPEC group according to the WHO are permitted to detect other pathotype E. coli groups like ETEC and EHEC in this study. Nine serogroups were identified in this study. Among the identified serogroups, the O114 serogroup was the most isolated. This serogroup has been the cause of an epidemic of infantile gastroenteritis in England [42].

\section{Conclusion}

This study shows the presence of pathotypes of E. coli in water, sediment, and crab. The pathogenic E. coli belongs to two different pathotypes: ETEC and EHEC. ETEC represented the most frequent pathotype. Nonpathogenic strains of $E$. coli were also identified in all samples analyzed, especially in fish samples. Nine serogroups have been identified with $\mathrm{O} 114$ as majority group. This study shows the importance of controlling sources of human fecal pollution, such as municipal wastewater management, to reduce potential risks to human health. In this sense, all latrines built on pile should be suppressed. The domestic water must also be treated before being discharged into the lagoon. 
TABLE 6: Relationship between virulence genes and $\mathrm{O}$ antigens.

\begin{tabular}{|c|c|c|}
\hline Strains & Genes & Serogroups \\
\hline S1 & est, elt & ND \\
\hline S2 & est, elt & $\mathrm{O} 114$ \\
\hline S3 & elt & ND \\
\hline $\mathrm{E} 1$ & est & ND \\
\hline E2 & stx, elt & O55 \\
\hline $\mathrm{C} 1$ & est, elt & O114 \\
\hline S4 & est, elt & $\mathrm{O} 114$ \\
\hline S5 & est, elt & O114 \\
\hline E3 & est & ND \\
\hline $\mathrm{E} 4$ & est, elt & ND \\
\hline E5 & est & O127 \\
\hline S6 & est & ND \\
\hline E6 & stx, est & O114 \\
\hline E7 & est & O111 \\
\hline S7 & $s t x$ & ND \\
\hline E8 & elt & ND \\
\hline E9 & $s t x$ & $\mathrm{ND}$ \\
\hline E10 & est, elt & ND \\
\hline S8 & est, elt & ND \\
\hline E11 & est, elt & O127 \\
\hline S9 & elt & ND \\
\hline E12 & elt & ND \\
\hline S10 & elt & ND \\
\hline E13 & est, elt & O114 \\
\hline E14 & est, elt & ND \\
\hline E15 & est, elt & ND \\
\hline E16 & elt & ND \\
\hline S11 & est, elt & O114 \\
\hline E17 & est & ND \\
\hline E18 & est & ND \\
\hline E41 & est, elt & ND \\
\hline E19 & est, elt & ND \\
\hline E20 & est & O114 \\
\hline E21 & $s t x$ & O127 \\
\hline E22 & elt & ND \\
\hline E23 & est & O126 \\
\hline $\mathrm{S} 12$ & est & O127 \\
\hline E24 & est & ND \\
\hline E25 & est & ND \\
\hline E26 & est & ND \\
\hline $\mathrm{S} 13$ & est & ND \\
\hline $\mathrm{E} 42$ & est & $\mathrm{ND}$ \\
\hline E27 & elt & ND \\
\hline E28 & est, elt & ND \\
\hline E29 & est & ND \\
\hline S14 & est, elt & O55 \\
\hline E30 & est & O142 \\
\hline E31 & est & O128 \\
\hline S15 & est, elt & ND \\
\hline
\end{tabular}

TABle 6: Continued.

\begin{tabular}{lcc}
\hline Strains & Genes & Serogroups \\
\hline E32 & elt & ND \\
E33 & stx & ND \\
E34 & est & O119 \\
S16 & est & O55 \\
S17 & est & O114 \\
E35 & est, elt & O86 \\
E36 & est & ND \\
E37 & elt & ND \\
E38 & est, elt & ND \\
E39 & elt & ND \\
S18 & est, elt & ND \\
E40 & est, elt & ND \\
S19 & est & ND \\
\hline
\end{tabular}

ND: not determined.

\section{Conflicts of Interest}

The authors declare that there are no conflicts of interest regarding the publication of this paper.

\section{Acknowledgments}

The authors are very grateful to Yoro Thierry Dezay for technical assistance during this study.

\section{References}

[1] J. P. Nataro and J. B. Kaper, "Diarrheagenic Escherichia coli," Clinical Microbiology Reviews, vol. 11, Article ID PMC121379, pp. 142-201, 1998.

[2] R. Mansan-Almeida, A. L. Pereira, and L. G. Giugliano, "Diffusely adherent Escherichia coli strains isolated from children and adults constitute two different populations," BMC Microbiology, vol. 13, no. 22, pp. 1-14, 2013.

[3] G. M. Grasso, M. L. Sammarco, G. Ripabelli, and I. Fanelli, "Enumeration of Escherichia coli and coliforms in surface water by multiple tube fermentation and membrane filter methods," Microbios, vol. 103, no. 405, Article ID 11092193, pp. 119-125, 2000.

[4] J. K. Tumwine, J. Thompson, M. Katua-Katua, M. Mujwajuzi, N. Johnstone, E. Wood et al., "Diarrhoea and effects of different water sources, sanitation and hygiene behaviour in East Africa," Tropical Medicine and International Health, vol. 7, no. 9, Article ID 12225505, pp. 750-756, 2002.

[5] L. C. Rúgeles, J. Bai, A. J. Martínez, M. C. Vanegas, and O. G. Gómez-Duarte, "Molecular characterization of diarrheagenic Escherichia coli strains from stools samples and food products in Colombia," International Journal of Food Microbiology, vol. 138, no. 3, pp. 282-286, 2010.

[6] I. B. Salem, I. Ouardani, M. Hassine, and M. Aouni, "Bacteriological and physico-chemical assessment of wastewater in different region of Tunisia: Impact on human health," $B M C$ Research Notes, vol. 4, no. 144, pp. 1-11, 2011.

[7] L. E. Merchant, H. Rempel, T. Forge et al., "Characterization of antibiotic-resistant and potentially pathogenic Escherichia colifrom soil fertilized with litter of broiler chickens fed 
antimicrobial-supplemented diets," Canadian Journal of Microbiology, vol. 58, no. 9, pp. 1084-1098, 2012.

[8] Y. Cui, D. F. Li, and R. F. Yang, "Yang.Shiga toxin-producing Escherichia coli O104:H4: an emerging important pathogen in food safety," Chinese Science Bulletin, vol. 58, no. 14, pp. 16251631, 2013.

[9] E. Oswald, H. Schmidt, S. Morabito, H. Karch, O. Marchès, and A. Caprioli, "Typing of intimin genes in human and animal enterohemorrhagic and enteropathogenic Escherichia coli: characterization of a new intimin variant," Infection and Immunity, vol. 68, no. 1, Article ID PMC97102, pp. 64-71, 2000.

[10] C. C. Bii, T. T. Taguchi, L. W. Ouko, N. Muita, and S. Kamiya, "Detection of virulence related genes by multiplex PCR in multidrug-resistance diarrheagenic $E$. coli isolates from Kenya and Japan," Epidemiology and Infection, vol. 133, pp. 627-633, 2005.

[11] C. A. Wanke, "Enteropathogenic and enteroaggregative strains of Escherichia coli: clinical features of infection, epidemiology, and pathogenesis," Current Clinical Topics in Infectious Diseases, vol. 14, pp. 230-252, 1995.

[12] S. C. Clarke, R. D. Haigh, P. P. Freestone, and P. H. Williams, "Virulence of enteropathogenic Escherichia coli, a global pathogen," Clinical Microbiology Reviews, vol. 16, no. 3, pp. 365378, 2003.

[13] J. E. Blanco, G. Dahbi, A. Mora, M. P. Alonso, and G. Varela, "al..Typing of intimin (eae) genes from enteropathogenic Escherichia coli (EPEC) isolated from children with diarrhea in Montevideo Uruguay: identification of two novel intimin variants ( $\mu \mathrm{B}$ and $\xi \mathrm{R} / \beta 2 \mathrm{~B}$," Journal of Medical Microbiology, vol. 55, Article ID 16914645, pp. 1165-1174, 2006.

[14] C. L. Obi, E. Green, P. O. Bessong, B. De Villiers, A. A. Hoosen, E. O. Igumbor et al., "Gene encoding virulence markers among Escherichia coli isolates from diarrhoeic stool samples and river sources in rural Venda communities of South Africa," Water SA, vol. 30, no. 1, pp. 37-42, 2004.

[15] T. Ndlovu, M. Le Roux, W. Khan, and S. Khan, "Co-detection of virulent Escherichia coli genes in surface water sources," PLoS ONE, vol. 10, no. 2, Article ID e0116808, 2015.

[16] Y. Titilawo, L. Obi, and A. Okoh, "Occurrence of virulence gene signatures associated with diarrhoeagenic and non-diarrhoeagenic pathovars of Escherichia coli isolates from some selected rivers in South-Western Nigeria," BMC Microbiology, vol. 15, no. 204, pp. 1-14, 2015.

[17] M. J. Hamilton, A. Z. Hadi, J. F. Griffith, S. Ishii, and M. J. Sadowsky, "Large scale analysis of virulence genes in Escherichia coli strains isolated from Avalon Bay, CA," Water Research, vol. 44, no. 18, pp. 5463-5473, 2010.

[18] C. L. Lauber, L. Glatzer, and R. L. Sinsabaugh, "Prevalence of pathogenic Escherichia coli in recreational waters," Journal of Great Lakes Research, vol. 29, no. 2, pp. 301-306, 2003.

[19] Y. Sankare, T. Joanny, and J. B. Amon-Kothias, "Evaluation des ressources maritimes halieutiques démersales et thonières de la Côte d'Ivoire," Rapport d'exécution de Convention CRO/PAGDRH, vol. 120, 2010.

[20] J. M. Rangel, P. H. Sparling, C. Crowe, P. M. Griffin, and D. L. Swerdlow, "Epidemiology of Escherichia coli O157:H7 outbreaks, United States, 1982-2002," Emerging Infectious Diseases, vol. 11, pp. 603-609, 2005.

[21] O. Kambire, A. A. Adingra, S. G. Eblin, N. AKA, A. C. Kakou, and N. R. Koffi, "Caractérisation des eaux d'une lagune estuarienne de la Côte d'Ivoire: la lagune Aby," Larhyss Journal, vol. 20, pp. 95-110, 2014.
[22] N. H. Nguyen, M. C. Tô, M. Carles, A. Tripodi, and G. Bodin, "Etude de 91 souches d'Escherichia coli responsables de la maladie de l'œdème du porcelet dans le sud du Viet," Nam. Revue Méd. Vét, vol. 151, pp. 23-32, 2000.

[23] C. Toma, Y. Lu, N. Higa et al., "Multiplex PCR assay for identification of human diarrheagenic Escherichia coli," Journal of Clinical Microbiology, vol. 41, no. 6, pp. 2669-2671, 2003.

[24] E. Oswald, H. Schmidt, S. Morabito, H. Karch, O. Marches, and A. Caprioli, "Typing of intimin genes in human and animal enterohemorrhagic and enteropathogenic Escherichia coli: characterization of a new intimin variant," Infection and Immunity, vol. 68, no. 1, Article ID PMC97102, pp. 64-71, 2000.

[25] S. Yamasaki, Z. Lin, H. Shirai et al., "Typing of verotoxins by DNA colony hybridization with poly- and oligonucleotide probes, a bead-enzyme-linked immunosorbent assay, and polymerase chain reaction," Microbiology and Immunology, vol. 40, no. 5, Article ID 8999287, pp. 345-352, 1996.

[26] O. A. Ratchtrachenchai, S. Subpasu, and K. Ito, "Investigation on enteroaggregative Escherichia coliinfection by multiplex PCR," Bull. Dept. Med. Sci, vol. 39, no. 4, pp. 211-220, 1997.

[27] Z. Tamanai-Shacoori, A. Jolivet-Gougeon, M. Pommepuy, M. Cormier, and R. R. Colwell, "Detection of enterotoxigenic Escherichia coli in water by polymerase chain reaction amplification and hybridization," Canadian Journal of Microbiology, vol. 40, no. 4, pp. 243-249, 1994.

[28] E. Hornes, Y. Wasteson, and O. Olsvik, "Detection of Escherichia coli heat-stable enterotoxin genes in pig stool specimens by an immobilized, colorimetric, nested polymerase chain reaction," Journal of Clinical Microbiology, vol. 29, no. 11, pp. 2375-2379, 1991.

[29] O. Kambiré, A. A. Adingra, C. A. Kakou, and R. Koffi-Nevry, "Indicateurs de pollution fécale dans une lagune tropicale à forte influence continentale (lagune Aby, Côte d'Ivoire)," Agronomie Africaine, vol. 24, no. 2, pp. 89-100, 2012.

[30] S. Bekal, R. Brousseau, L. Masson, G. Prefontaine, J. Fairbrother, and J. Harel, "Rapid identification of Escherichia coli pathotypes by virulence gene detection with DNA microarrays," Journal of Clinical Microbiology, vol. 41, no. 5, pp. 2113-2125, 2003.

[31] F. Qadri, A. M. Svennerholm, A. S. G. Faruque, and R. B. Sack, "Enterotoxigenic Escherichia coliin developing countries: epidemiology, microbiology, clinical features, treatment, and prevention," Clinical Microbiology Reviews, vol. 18, pp. 465-484, 2005.

[32] K. D. Nessa, J. Ahmed, F. L. Islam, Kabir, and A. M. Hossain, "Usefulness of a multiplex PCR for detection of diarrheagenic Escherichia coli in a diagnostic microbiology laboratory setting," Bangladesh J. Med. Microbiol, vol. 1, no. 2, pp. 38-42, 2007.

[33] H. I. Shaheen, S. B. Khalil, M. R. Rao et al., "Phenotypic profiles of enterotoxigenic Escherichia coli associated with early childhood diarrhea in rural Egypt," Journal of Clinical Microbiology, vol. 42, no. 12, pp. 5588-5595, 2004.

[34] K. A. Sehand and I. F. S. Layla, "Identification of different categories of diarrheagenic Escherichia coli in Stool samples by using Multiplex PCR technique," Asian Journal of Medical Sciences, vol. 2, no. 5, pp. 237-243, 2010.

[35] K. R. S. Aranda, S. H. Fabbricotti, U. Fagundes-Neto, and I. C. A. Scaletsky, "Single multiplex assay to identify simultaneously enteropathogenic, enteroaggregative, enterotoxigenic, enteroinvasive and Shiga toxin-producing Escherichia coli strains in Brazilian children," FEMS Microbiology Letters, vol. 267, no. 2, pp. 145-150, 2007. 
[36] S. Kalnauwakul, M. Phengmak, U. Kongmuang, Y. Nakaguchi, and M. Nishibuchi, "Examination of diarrheal stools in Hat Yai City, South Thailand, for Escherichia coli O157 and other diarrheagenic Escherichia coli using immunomagnetic separation and PCR method," Southeast Asian Journal of Tropical Medicine and Public Health, vol. 38, no. 5, pp. 871-880, 2007.

[37] S. K. Munshi, M. M. Rahman, and R. Noor, "Detection of Virulence Potential of Diarrhoeagenic Escherichia coli Isolated from Surface Water of Rivers Surrounding Dhaka City," Journal of Bangladesh Academy of Sciences, vol. 36, no. 1, pp. 109-121, 2012.

[38] A. Dadié, T. Karou, N. Adom, A. Kétté, and M. Dosso, "Isolement d'agents pathogènes entériques en Côte d'Ivoire Escherichia coli O157:H7 et E. coli entéroagrégant," Bull. Soc. Pathol. Exot, vol. 93, pp. 95-96, 2000.

[39] P. Y. Moalic and J. L. Guennec, "Prévalence des facteurs de virulence de souches d'Escherichia coli responsables de diarrhées chez le porc en France," Revue de Médecine Vétérinaire, vol. 6, no. 151, pp. 523-526, 2000.

[40] J. P. S. Sidhu, A. Warish, L. Hodgers, and S. Toze, "Occurrence of virulence genes associated with diarrheagenic pathotypes in Escherichia coliisolates from surface water," Applied Environmental Microbiology, pp. 328-335, 2013.

[41] S. J. Moyo, S. Y. Maselle, M. I. Matee, N. Langeland, and H. Mylvaganam, "Identification of diarrheagenic Escherichia coli isolated from infants and children in Dar es Salaam, Tanzania," BMC Infectious Diseases, vol. 7, article 92, pp. 1-7, 2007.

[42] S. Jacobs, A. Holzel, B. Wolman et al., "Outbreak of infantile gastro-enteritis caused by Escherichia coli 0114," Archives of Disease in Childhood, vol. 45, pp. 656-663, 1970. 

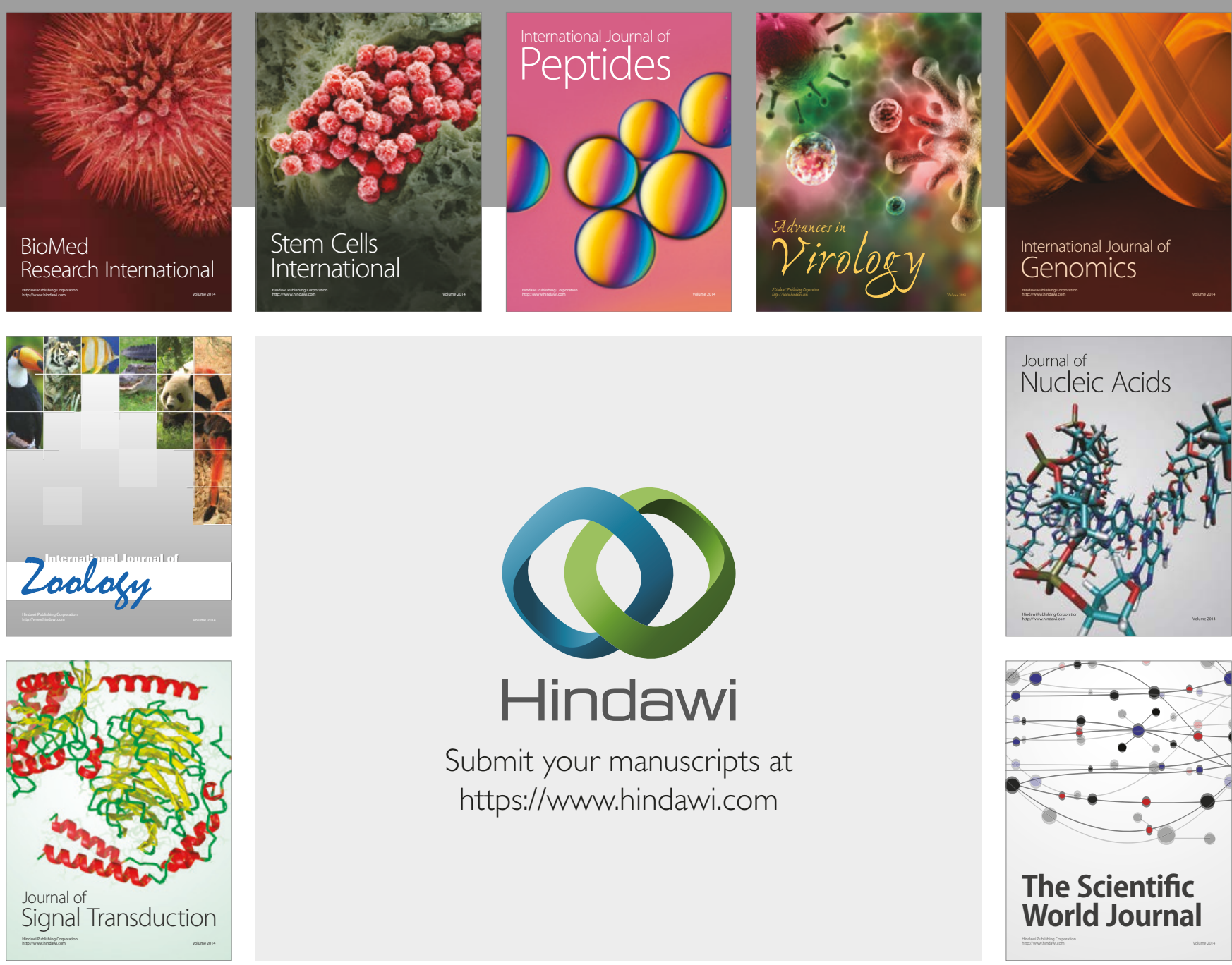

Submit your manuscripts at

https://www.hindawi.com
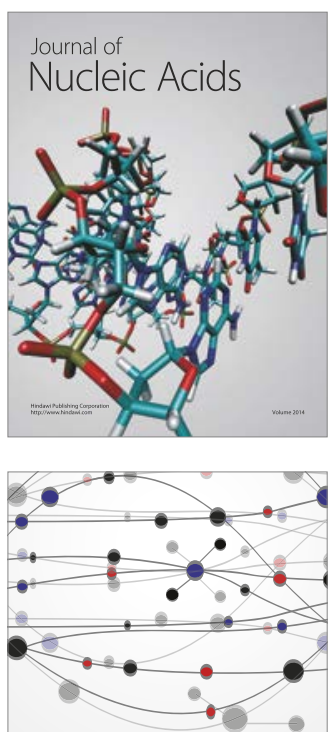

The Scientific World Journal

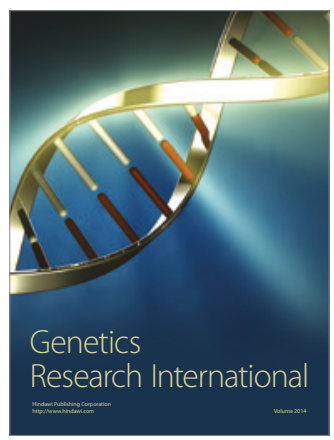

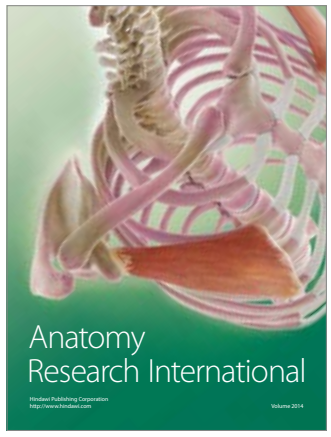

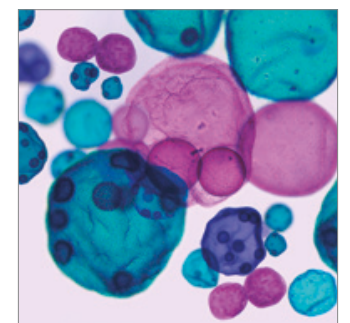

International Journal of Microbiology
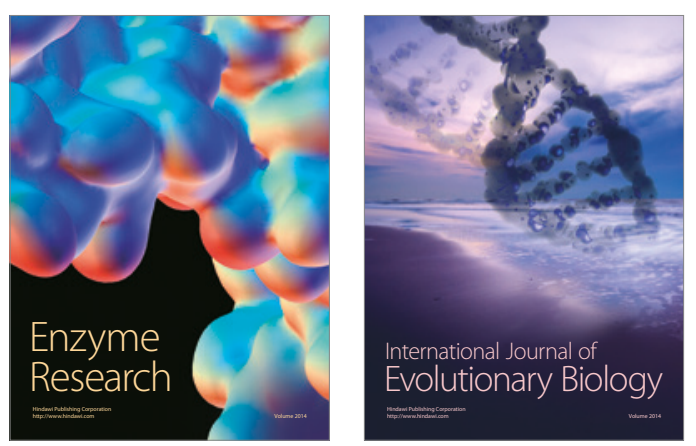
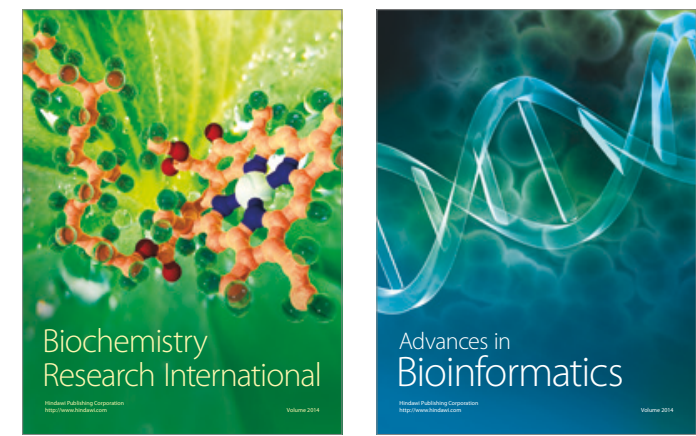

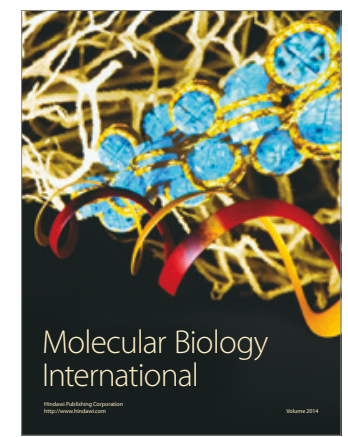

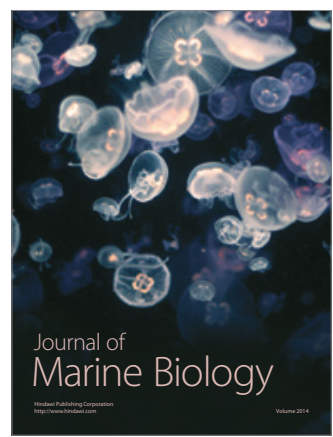

